\title{
ETHICS IN RESEARCH
}

\author{
By Mark Campbell Williams, \\ Faculty of Business and Public Management, \\ School of Management Information Systems \\ ECU (Edith Cowan University) \\ Churchlands, WA 6018 \\ Email: m.williams@cowan.edu.au
}

\begin{abstract}
In order to reflect on some ethical improprieties which I had committed during the data collection phase of an information systems research study, I conducted an heuristic and psychologically-oriented self-study. As part of this heuristic reflection, I engaged in a number of self dialogues in the form of a conversation between various characters. Reported in this paper is one of these dialogues, concerning broad issues of ethics and research and discussing the notion of wisdom, maturity, meaning, and virtue. Ethical considerations are always of primary importance, and I would assert that this is even more so when considering research investigating and using new media, such as the world wide web, in which acceptable ethical practices have yet to be established and consolidated.
\end{abstract}

Keywords: Ethics, research, dialogue, wisdom, virtue

\section{INTRODUCTION}

In this paper, which builds upon my presentation at the 1999 Australian Conference of Information Systems (Williams, 1999), I present an autobiographical account of my five years as a teacher and researcher investigating a teaching reform of the first-year Undergraduate Business Computing Course for the Bachelor of Business degree at the University at which I was employed from 1991 to 1995 . I was progressively a tutor, then a lecturer, then the Course Coordinator facilitating the reform of the Course. My research began in late 1991 as a qualitative investigation with the implicit hypothesis that open discourse could balance technicism in the University Business Computing classes taught by myself and three colleagues. The basic idea of the reform was to encourage communication and discourse about the meaning and purpose and wider societal implications of business computing in addition to the narrowly technical aspects.

I present a description of the research and a conversation conceming the general issue of ethics in research, structured loosely around an idea of wisdom with some keywords of maturity, meaning and virtue. This discussion is presented in the form of a conversation between several persons with which I coordinated an exchange of comments concerning qualitative research. Overall, I considered that my responsibility, to myself, to the participants and to the research community, was to tell my story, with as much maturity, meaning and virtue as I could.

\section{OPEN DISCOURSE AND TECHNICISM}

Open discourse is communication concerning personal and social meaning, purpose, orientation, values, goals, concepts, ideas, feelings and emotions relevant to, but distinct from, the narrow subject matter, technique and administration of University Business Computing education. In a University Business Computing tutorial, for example, open discourse could occur in the initial introductions of the participants or in initial statements of the meaning and purpose of the subject to students' life situations or goals. Any discourse specifically concerned with matters of computing techniques or the terminology of the text would not be open discourse (although open discourse may occur if the discussion broadens to include personal, historical or societal issues relating to the meaning or purpose of the techniques).

Open discourse does not necessarily have to be formal small group or whole group discussion. It may even be a passing comment to an individual student after the end of the computing laboratory, or an informal chat to a group of students in the campus grounds, or even a note on assessing a student's work (written communication can also be discourse). The teacher and students can be autonomous, free, well-rounded human beings able to engage in meaningful and balanced discourse even in spite of a technicist curriculum (Taylor and Campbell Williams, 1993b).

Technicism is an over-emphasis on technical, instrumental or strategic techniques or actions, to the detriment of wider human communication, human values or human purpose (Adomo \& Horkheimer, 1990; Dryzek, 1990; Ellul, 1990; Habermas, 1972; Marcuse, 1964, 1969). Persons thinking in technicist ways would tend to define all human problems in terms of rational and technical solutions, thus leading to an undue emphasis on the science, instrumental rationality and technology of the modern age (Bowers, 1988, 1993 a, 1993 b; Ellul, 1964, 1973; Habermas, 1971). 


\section{THE TEACHING REFORM}

The essence of the reform was to encourage open discourse (a form of communicative rationality) by introducing teaching and leaming strategies such as group work, a dialogical communication process in the tutorials and mass lectures, and requiring students to keep personal learning journals. The first phase of my research, from 1991 to 1993, was an interpretive qualitative investigation with the implicit hypothesis that the teaching strategies would encourage communicative rationality through open discourse and balance the dominating instrumental rationality of technicism. However, in 1993, through a component of self-study in the research, I came to understand that I, personally, had succumbed to a form of unbalanced and inappropriate instrumental rationality (a strategic rationality) in my conduct of the research. I had imposed the teaching strategies on the students and tutors without fully informing them and without fully gaining their consent. In order to reflect on my unethical practice, I conducted a heuristic and psychologically-oriented self-study from 1993 to 1996. The research question was "what was the underlying reasons for the ethical shortcomings of my flawed investigation of 1991 to 1993, and how could I address this?". Thus reporting on a dialogical interplay between outer-oriented and subjectively inner-oriented aspects of technicism and discourse, I explore that dimension of the self-study of teaching which includes the psychologically-oriented study of self.

\section{BACKGROUND THEORY}

For more than 20 years, in Australia and overseas, I have been involved in high school teaching, then Technical and Further Education, then industry computer based training consulting and now University Computing Education. My work in education has been immeasurably enriched by the advent of microcomputers and I have seen many students, especially the handicapped and those who do not score well in scholastic tests, display uncharacteristic enthusiasm for their education and sometimes achieve remarkable results through using this technology.

So, regarding the increased use of microcomputers in education, one part of me is positive and enthusiastic. There is another aspect of myself, however, that remains concerned and critical about some aspects of the impact of computing technology on the teaching-learning process.

The keyboard enables us to give orders without personal contact. We have a collection of individuals without personal contact. We have a collection of individuals without interaction (except in terms of technique or by means of it). (Prof. Jacques Ellul, 1990, )

Jacques Ellul's 40 years of (rather French) polemic against the dangers of "la technique" (Ellul, 1964; 1990) forms a consistent critique of technicism and the sort of scenario portrayed by Lewis. For Ellul, technique is a ubiquitous and hegemonic force that dominates modernity and is reductionist in reducing human experience to matters of method and efficacy. Pithily describing the essence of technicism, Ellul (1990) comments wryly in regard to the optimism of a technicist economist: "Whenever a difficulty arises, 'technical progress will deal with it"' (p. 21).

Understood in this way, technique can be seen as more than just technological, but as a social and psychological commitment with the added dimension of a faith in technical progress - Ellul understands technique as a spiritual force (1990, pp. 405-411). Technique acts to close off all avenues of human resistance to what Ellul prophesies as the spiralling descent of modernity's commitment to technical progress. It acts to create a monolithic evangelising mindset which stifles any criticism or true debate about other ways of knowing or being: "The intellectual and cultural tragedy of the modem world is that we are in a technical milieu that does not allow reflection" (1990, p. 145). Ellul continues:

Are we then shut up, blocked, and chained by the inevitability of the technical system which is making us march like obedient automatons thanks to its bluff? Yes, we are radically determined. . . Not really ... we profit from the little cracks of freedom, and install in them a trembling freedom which is not attributed to or mediated by machines. (Prof. Jacques Ellul, 1990, )

In his last major work, The Technological Bluff (1990), Ellul considers that education has been taken over by what he terms "terrorism in the velvet glove of technology" (pp. 389-394). In most major national political agendas, Ellul perceives a non-reflective and hegemonic push for technique-oriented pedagogy in the form of computer-mediated education which "in some sense falsifies everything that traditional culture has slowly developed" (p. 391). In the quotation which begins this section, he ended the book by alluding to a possible hope for action in a technically determined future. His hope was that, by radically critical reflection, by a critique of the bluff of technological propaganda, by exploring "little cracks of freedom", individuals may be able, by what he terms "the sole aptitude of astonishment", to "truly invent the new thing" (1990, p. 412). 


\section{A conversation concerning ethics}

In this paper, I present a conversation concerning the general issue of ethics in research, structured loosely around an idea of wisdom with some keywords of maturity, meaning and virtue. This discussion is presented in the form of a conversation between several persons. I coordinated an exchange of comments, concerning qualitative research, between Mr Craig Standing, Dr Peter Taylor, Dr Peter Standen and myself. With their permission, I extensively edited, expanded, and added to the dialogue to change the themes and content to suit my own purposes. To protect my colleagues, and to clearly signal the fictive nature of the dialogue, I use the names Bill, Bob, Ben.

Mark: It seems to me that some folk, including those that are normally wise and ethical, act in an unusually 'loose' manner when using computers and the web. I have experienced cases when researchers, not only students, act with gay abandon in copying and plagiarising material from the web. It is my opinion that ethical procedures and practices take considerable time to become established and consolidated in new media and new situations. Also, some researchers are so concerned about research rigour that, it seems to me, they sometimes neglect important qualitative or intuitive human concerns. Rather than using the word "ethics", perhaps we should begin by considering the concept of wisdom.

Bill: When using the word wisdom, I take it that you are talking from a value-laden framework that you think is preferable and can be used across multiple frameworks to guide the process of researching. I would like to hear more about this metaphor for I am thinking along the same line. Too many of us seem to be under a great burden, perhaps under the name of rigour, to achieve acceptability in academia.

Mark: In your first insight you are correct, and I agree with your second comment. I follow what is known as a virtue theory especially as it has been expounded by Alasdair MacIntyre (1984) in his book Beyond Virtue: A Study in Moral Theory. As I understand him, MacIntyre asserted that wisdom can only be lived out in a virtuous life, informed by multiple ways of knowing and learning, in community. As Bowers commented, community is: "based on some conception of how a good person acts" (1993, p. 87). Wisdom can be passed on only through a kind of apprenticeship in a way analogous to a bird teaching its young to fly. Wisdom, itself, seems to be part of the warp and weave of life bound up with constitutive forms of knowledge - rational and non-rational, conscious and unconscious, cerebral and somatic, logical and intuitive, emotional and holistic - these and more. Linguistically, it is primarily in the form of moral, metaphorical narratives which represent the community's stored understanding and wisdom. C. A. Bowers is much taken by these ideas, quoting Macintyre's comment: "The narrative of any one life is part of an interlocking set of narratives" (cited in Bowers, 1993, p. 87). Bowers (1993) compared this understanding with the limited understandings of some computing experts. He asserted that these forms of knowledge (what I term wisdom): "cannot be made explicit and re-encoded to fit the digital technology required for computer-mediated communication" (p. 86, 87). When I use the term wisdom, I am thinking of the virtue of wisdom in this broad sense. Allow me to present pictorially some key words which may stimulate our discussion (see Fig. 1).

Bob: One must strive for objectivity. It is difficult for the social sciences to achieve the miracles of the physical sciences, but researchers must strive to use the methods of the physical sciences.

Ben: What about that research in the social sciences which is difficult to replicate and, due to inherent subjectivity, almost impossible not to subtly influence the outcome? I am no positivist. In fact, I speculate that the whole idea of academic positivism became a device to lead the researcher to maturity and morality. In other words, to promote a type of wisdom. In the physical sciences, quantitative research was sufficiently limited and narrow that other researchers could replicate the experiment to test its validity. However, in the social sciences very few interventions could be reproduced in a way that could attest to the validity of the original research. Perhaps the intellectual community evolved elaborate rules to restrict the issue and help researchers resist the temptation to use immature rhetoric (or to lie for recognition, or whatever). The hope may have been that, if students were trained in academic (sometimes esoteric) rules, then they would develop their intellect and thus grow in wisdom (outworked in maturity and morality). However, we are all aware of the history of academic and scientific fraud. I have some anecdotal evidence in that, of the eight or so academics with whom I have spoken informally regarding their theses, three openly said that they committed academic fraud (and this was in three of the most respected universities in the Western world). There are other ways to lead people to wisdom for example, the adoption of a moral framework which is often the outworking of a religious commitment. 


\section{WISDOM IN TEACHING, LEARNING, RESEARCHING \& WRITING}

experience and knowledge together with the power of applying them critically or practically

MATURITY

being duly careful and adequate as a developed person - ESPECIALLY

1. BALANCE: a stability of mind; an equilibrium of instrumental action with communicative interaction

\section{THOROUGHNESS: not} superficial; done with care, completeness and context

3. RIGOUR: strictness and logical exactitude

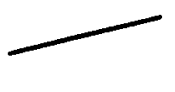

MEANING

pursuing that which is considered significant and important - ESPECIALLY

1. PURPOSE: intention, resolution, and a reason for endeavour

2. DIRECTION: a way or course for endeavour

3. INTEREST: a feeling of curiosity or concern, can be a passion

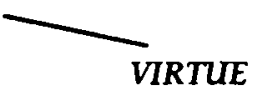

virtuous character or behaviour; a good moral quality, as justice ESPECLALLY

1.TRUTHFULNESS: esp. make known or reveal one s opinions, biases, interests. motivations and agendas (incl. unconscious)

2. HONESTY: truthful, fair and just in character and behaviour

3. COMMITMENT: dedication and application in a pledge or undertaking

Figure 1. Thinking about of wisdom in teaching, learning, researching and writing

Mark: Whatever the case, the post-Enlightenment thinkers who formulated the academic rules developed a rigid system of experimental quantitative rigour (Bowers, 1992). This restricted approach has been seriously questioned originally by neo-Calvinist philosophy in the early twentieth century (Doowerweerd, 1979) and then by postmodernism, poststructuralism, feminism (Caraca \& Carrilho, 1994) and neo-Marxism (Bowers, 1992). I like the viewpoint of Caraca and Carrilho (1994) when they commended us to "think of knowledge and particularly scientific knowledge not as the application of a previously established method aimed also at achieving previously determined ends, but as an invention of strategies for discovery, legitimation and communication, for which the rhetoric of science may perhaps come to provide a rather unexpected picture for many" (p. 786). In my researching, I endeavour to explore ways to be rigorous and yet to be passionate. As Eisner (1992) recommended: "When you have a conviction about what you believe is important to study or how you think it should be studied, my advice to you is to pursue that conviction."

Bob: You have conveniently ignored the history of the last 500 years here! Scientific method, because it is an open system of knowledge acquisition, became popular precisely because it liberated us from moral philosophy that enslaved. Remember Galileo at the Spanish Inquisition? What about the role of religious 'wisdom' in increasing the happiness of the human races - from the ritual sacrifices of the Aztecs through the Dark Ages to its peak in the Inquisition and the enslavery of the Third World in the 1500-1600s? Scientific method was one of the major ways we rid the world of these tyrannies, by enabling anyone to come up with openly debatable and verifiable answers to fundamental questions such as whether the earth is flat, or is the centre of the Universe. The realities espoused by wise folk such as witchdoctors, prophets and popes were found wrong. What other method could have achieved this?

Ben: Bob, I am surprised that you have not grasped the deeper currents of history. Critical theory, postmodernism and deep ecology have clearly revealed the deeply-embedded violence inherent in scientific consciousness. It is open only in so far as one treads a narrow epistemology. You should remember that it was the secular political inquisition which was the most barbaric (people often deliberately blasphemed at the crucial moment so that they would be tried by the more 'reasonable' religious inquisition). And both these pale before the terrible inquisitions of the Enlightenment French revolution terrors through to the Nazi holocausts and right up to Pol Pot. The Enlightenment project, with science as its talisman, was originally empowering, but the seeds of its enslaving agenda were within its original mandate to dominate nature. Ghastly destruction has been wrought by scientistic positivism - not only in its application for the weapons of war. In one way, scientific and technological instrumental rationality has proven to be more 'wrong' and more disastrous for planetary ecology than all the witchdoctors, prophets and popes put together!

Mark: I think that there is something important in what you say, Ben. Adorno and Horkheimer (1990), Ellul (1964), Marcuse (1969), and a host of other major social philosophers from Nietzsche (1968) onwards drew attention to the way in which Enlightenment thinking is now a debased and enslaving hegemony of modemity. But Bob is surely true in pointing us to the social and personal benefits of free critical thinking, in freeing 
generations of people from the enslaving hegemonies of the debased authoritarian religious and monarchist institutions of the eighteenth century right up to the present.

Bill: This may be true, but these historical and philosophical currents are rather beyond the scope of our discussion at the moment. I think that both Ben and Bob are arguing for a balance. Eisner (1992) reminds us that "scientific research writing, in the end, is a construction and the more artistic in character, the better." The debate is leading us to move from the narrow metaphor of rigour in research writing back to the fundamental questions of why we research at all. Of course, for a lot of academics and researchers, researching is a job and not much more - you do what you can get away with and what gives you promotion and acclaim.

Ben: I also have found instances of this lazy approach, but other persons have something more like a faith in the scientific or Enlightenment project (Goudzwaard, 1979). They believe that this rational scientific method will progressively solve our social, cultural and even personal problems - all we need is more progress in scientific knowledge and concomitant technological wizardry! This results in a type of positivism which is close to a religious faith (Adorno \& Horkheimer, 1992).

Mark: I prefer to place my faith elsewhere.

Bill: Hmmm ... Perhaps we should return to the wisdom diagram (Fig. 1). Using this wisdom in teachinglearning-researching and writing metaphor, we should ask some key questions.

Mark: The central question becomes: "Does the teacher-learner-researcher-writer demonstrate wisdom?". The corollary questions become; "Does the teacher-learner-researcher-writer demonstrate maturity (i.e. balance and thoroughness and rigour) and meaning (a sense of purpose and direction and even, I would argue, a controlling and controlled passion - at least an interest - for the subject) and virtue (not only in not lying - honesty - but in 'coming clean' in self-disclosure (Moustakas \& Douglas, 1985, p. 50), revealing one's consciously understood world-view belief systems and interests in the subject as well as what can be gleaned of one's unconscious drives, emotions and motivations; and in having the commitment to continue). At certain times and in certain areas of researching it would be wise to subsume certain areas of maturity (rigour) for the greater purposes of meaning and morality - rigour is only part of maturity which is, in turn, only a part of wisdom. However, as one reviewer commented, someone might say that I use the previous sentence for politically-oriented strategic action to authorise careless research. In the end, I have come to the conclusion that the wise choice is the one that is consistent with what Guba and Lincoln (1989) term quality, or goodness of the research, or, for heuristic research what Moustakas (1990) terms validity.

\section{CONCLUDING DISCUSSION}

As a result of my heuristic reflection, I did change my teaching practice in my University Business Computing courses. I now endeavour to provide rich learning environments in our classes by continuing the initiatives I had incorporated in the first phase, but in a more relaxed and gentle manner. I also incorporate the stretching and mental relaxation exercises suggested by von Wodke (1993) into the computer laboratories.

O'Connor's (1981) research suggests that many people between the ages of 35 to 45 years go through a transitional stage in which attention to psychological development would be of considerable benefit. If teachers or researchers, or anyone for that matter, find themselves operating unethically, perhaps they need some form of inner work. However, I think that most researchers and teachers would benefit by doing some form of reflexive practice and basic self-management training, especially interpersonal communication skills.

My tentative conclusion is that the deeper levels of the human psyche, if not recognised and honoured in dialogue, will (paraphrasing Norris, 1992, p.180) disrupt even (especially?) our most noble and well-framed attempts at educational reform. Could it not be that respecting and dialoguing with the deeper levels of the human psyche could lead to a fuller understanding of, and lay the foundations for, more psychologically whole and balanced teaching, researching, writing, and learning (and going wrong?).

It is interesting that post-modernism and critical social theory, two challenging influences on recent systems thinking (Flood, 1988; Flood and Jackson, 1991), both draw heavily on Freud's metapsychology (Osbome, 1992). I understand from postmodernist deconstruction, that any text is open to be understood on many levels. It is not a matter of understanding subconscious motives of the author, but rather attention to the text (or drawing) itself, rather than to the author (Poole, R. 1988, pp. 205, 206). Deconstruction of a text should not cause the author to feel uncomfortable. It is in the play of language itself that other meanings in texts inevitably surface. In his book The Postcard: From Socrtes to Freud, Derrida (1987) deconstructs a medieval drawing of Socrates and Plato to bring to the surface the strange ways in which the human mind defies reductionist understanding.

I emphasise that this paper is largely tentative. I autobiographically describe understandings and experiences of 
technicism and open discourse in the outer world of the University Business Computing teaching reform, and in the inner world of my own pedagogical self. This is a complex notion. Jung (1968) contends that the dialogue between the outer and inner worlds, the conscious and the unconscious, although of vital importance in almost every area of human pursuit, is often neglected, usually at a cost. I explored this dialogue in the context of reflecting heuristically on a teaching reform in a University Business Computing Course. I think that this conscious-unconscious dialogue is present in any research, and is pervasive in academia, but largely ignored, usually at a cost. For science in general, some would contend that lack of reflectivity, including lack of awareness of the unconscious, lies near the heart of some failures, perhaps the failure, of the scientific project of modernity (Adorno \& Horkheimer, 1990; Bowers, 1993 b; Habermas, 1972; Marcuse, 1964, 1969).

What price is the self? - or the soul? For some researchers the cost may be high. For myself, I allowed my zeal for teaching reform, based on critical theory, to mask the voices of my students and colleagues, and the voice of the self. I wonder: am I the only teacher or researcher to have succumbed to this temptation?

\section{REFERENCES}

Adorno, T, \& Horkheimer, M. (1992). The dialectic of enlightenment. London: Verso.

Barry, D. (1996). Artful Inquiry: A Symbolic Constructivist Framework for Social Science Research. Qualitative Inquiry 2 (4): $411-438$.

Barry, D. (1994), Making the Invisible Visible: Using Analogically-based Methods to Surface Unconscious Processes in Organizations. Organizational Development Journal 12 (4): 37-48.

Bowers, C. (1988). The cultural dimensions of educational computing: Understanding the non-neutrality of Technology. New York: Teachers College Press.

Bowers, C. (1993a). Critical essays on education, modernity, and the recovery of the ecological imperative. New York: Teachers College Press.

Bowers, C. (1993b). Education, cultural myths and the ecological crisis: towards deep change. Albany. New York: State University of New York Press.

Campbell Williams, M. (1995). The use of symbo-constructive pictures to explore the shadow side of our teaching-learning. In J. Abbott \& L. Willcoxson (Eds.), Proceedings of the Forum for Teaching and Learning in Higher Education (pp. 179-184), Murdoch University: Perth, Western Australia.

Checkland, P. \& Scholes, J. (1990). Soft Systems Methodology in Practice. London: Wiley.

Derrida, Jacques. (1987). The post card: from Socrates to Freud and beyond. (Alan Bass, Trans.). Chicago: University of Chicago Press.

Dryzek, J. S. (1990). Green Reason: Communicative Ethics for the Biosphere. Environmental Ethics 12(3), $195-211$.

Ellul, J. (1964). The technological society. New York: Knopf.

Ellul, J. (1973). The new demons. Oxford: Alden Press.

Ellul, J. (1990). The technological bluff. Michigan, U.S.A.: Eerdmans.

Flood, R. L. (1988). Situational complexity, systems modelling and methodology. Transactions of the Institute of Management and Control, 10 (3), 130-138

Flood, R. L. \& Jackson, M. C. (1991). Creative problem solving. United Kingdom: Wiley.

Habermas, J. (1971). Towards a rational society (Jeremy J. Shapiro, Trans.). London: Heinemann

Habermas, J. (1972). Knowledge and human interests (Jeremy J. Shapiro, Trans.). London: Heinemann.

Hicks, M. (1991). Problem Solving in Business and Management. London: Chapman and Hall.

Johnson, R. A. (1986). Inner Work: Using dreams and active imagination for personal growth. New York: HarperCollins.

Jung, C. G (1968). Approaching the unconscious. In C. J. Jung (Ed.), Man and his symbols (pp. 1-95). Aldus Books: London.

Jung, C. G. (1989) Memories, dreams, reflections (rev. ed.) (Richard \& Clara Winston, Trans.).New York: Vintage Books.

Lewis, C.S. (1978). The abolition of man. London: Fount.

Lewis, C.S. (1979). The great divorce. New York: MacMillan.

Marcuse, H. (1964) One dimensional man. London: Routledge and Kegan Paul.

Marcuse, H. (1969) Eros and civilisation. London: Allen Lane Penguin.

Moustakas, C. (1990). Heuristic research: Design, methodology and applications. Newbury Park: Sage.

Norris, C. (1992). Deconstruction, postmodernism and philosophy: Habermas on Derrida. In David Wood (Ed.), Derrida: A critical reader (pp. 167-192). Oxford: Blackwell.

Osborne, Richard. (1992). Philosophy for beginners. NY: Writers and Readers.

Poole, R. (1988). Deconstruction. In A. Bullock, O. Stallybrass \& S. Trombley (Eds.), Modern Thought: (rev. ed.). Glasgow: Fontana.

Standing, C. \& Campbell Williams, M. (1993 a). Methodological pluralism for managing departmental change: An interpretive action-research case study within a university information systems department. $\ln \mathrm{A}$. 
Herrman \& Colin Latchem (Ed.), Proceedings of the Forum for Teaching and Learning in Higher Education (pp. 173-184). Perth, Western Australia: Curtin University.

Standing, C. \& Campbell Williams, M. (1993 b). Business re-engineering from an IS perspective. Paper presented at the Information Technology Update' 93 conference, Edith Cowan University, Perth, Western Australia.

Standing, C. \& Campbell Williams, M. (1993 c). Methodological pluralism in a rapidly changing IT environment. In B. Glasson \& V. Pervan (Eds.), Proceedings of the International Federation of Information Processing Professionals Conference (pp. 23-25). Perth, Western Australia: Curtin University.

Taylor, P. \& Campbell Williams, M. (1993). Discourse towards balanced rationality in the high school mathematics classroom: Ideas from Habermas' critical theory. In J. Malone \& P. Taylor (Eds). Constructivist interpretations of teaching and learning mathematics (pp. 135-148). Perth, Western Australia: Curtin University of Technology.

von Wodke, M. (1993). Mind over media: creative thinking skills for electronic media. New York: McGrawHill.

Williams, M. Campbell (1999). Soft systems pictures: Reforming a university information systems course: Discussing a failure and an unusual research approach. In Hope, B., \& Yoong, P. (Eds). Proceedings of the Tenth Australasian Conference of Information Systerms, Wellington, New Zealand, Victoria University of Wellington.

Weizenbaum, J. (1977). Computer power and human learning. San Frānsisco: W. H. Freedman. 